\title{
What Is This Thing Called Geo-graphy? Episodes in the Theorizing of Geo-Human Interactions
}

\author{
Mahmood Shoorcheh* \\ Faculty of Geographical Sciences, KharazmiUniversity, Iran
}

Submission: June 18, 2018; Published: July 17, 2018

*Corresponding author: Mahmood Shoorcheh, Faculty of Geographical Sciences, KharazmiUniversity, 49 South Mfatteh Ave. Tehran, 1571914911, Iran, Email: shoorcheh.mahmood@gmail.com

\begin{abstract}
This article describes a personal perception of one of the most important issues in the geography science: new theorizations for new understandings of the newgeographies. New theories are among the major ambitions and forces in the development and promotion of geographic knowledge. However, what principlehas there been forgeographers for theorization? Can we track a common theme among geographic theories?This article attempts to explain that there is sucha common theme. Although this theme has meant different things to different people by different representations at different times and places, it has played the role of a common horizonto guide geographers in theorizing.This is an important point to comprehend the identity of geography as well aspedagogical purposes; because, based on such a reading, a researcher in geography will have a more coherent and systematic perspective towards the subject from the beginning of his/her research.
\end{abstract}

Keywords: Geographic Theories; Geo-Human Interactions; Genealogy; Geography Education

\section{Introduction}

Geographers have been exploring and deepening our geographical understanding of the Geo-human relations through different types of theories in different periods and various ways Hubbard et al.[1],Hubbard and Kitchin [2]. They have done this work by constructing, evaluating and refining new geographic theoriesto understand geographicity of relations between humanand $\mathrm{Geo}$ in terms of various conditions on different scales. In geography, most theorizations have been geographical readings of theGeo-human relationsthrough "philosophical/ethical", "natural/physical", "social/humanities", "economic", "political", "linguistic" and "sensual/aesthetic/ emotional"perceptions and used them as components of the constituent of new and independent geographical views/ theories that can be used in other disciplines.

The production of new theories in geography has a fundamental importance. They stimulate scientific actions inside and outside the academic communities. New theories play a driving role in understanding more and different aspects of Geo-human relations. Theories fill the black holes caused by the lack of geographic knowledge about the cause of some events in temporal-spatial conditions. Theories are not merely collections of geographical words or propositions, but they can help to unify and contribute to the coherence of geography and make this science distinct from other sciences. This is important when viewed from outside of geography. From this point of view, the position of theories in geography is very similar to a "linguistic
game"Shoorcheh [3]. Being aware or not, we are talking with a language. Just as we cannot properly speak without following some of the grammatical rules of a language, we cannot do a successful geographic research without choosing appropriate theories towards it.

Theories are always with us. As Harvey (1969: 486) says, "By our theories you shall know us". Even scholars who have no awareness about their theories, they have already chosen that by doing their own research. It is natural that geography has its own theories, and the theories in this science differ from that of other sciences Shoorcheh [4]. But what is the difference? Is there a criterion for comprehending this difference? What principles are the bases of theorizing by geographers? Can a general principle or theme be tracked in almost all of the geographic theories? The answers to these questions are the main concern of this study.

In order to answer the above questions through "geography's genealogy", it has been tried to explain how the geographic theories have always focused on the "spatialities of Geo-human interactions" and have been seeking to identify and explain the eventson the surface of Geo (as a natural/physical, abstract and social space)based on the "geographical spirit of times". This "geographical spirit" in different periods and with regard to the changes in human'sinteractions with the Geo and its realities, aspects of it has become the main concern of geography science and have been theorized by geographers based on a number of 
geographic concepts, reasons and representations. Accordingly, the purpose of this article is not to provide a single approach but instead it tries to provide a cognateness approach (same theme/ genre) to the nature of geographic theoriesby focusing on both the roots and routes of thinking on Geo-human relations.

A Brief Genealogy of Geography: New Theorizations for New Understandings of the New Geographies

In order to do such a study, it seemsthat "genealogy"is an appropriate historical method if we seek to understand how different theories are employed by human in various ways. In genealogy, there is a premise that theories are the detectors of the past, which is hidden by subsequent events. In addition, a genealogist seeks understanding through careful attention to the details of the historical records and not the spurious nature of the foundations of theories and categories. Therefore, there is no single and pure origin or a starting point through which the historical traditions are rooted in continuity without discontinuity. The work of genealogy ends where no information is available, but once the information is availablework continues again Mayhew [5].

To the extent that written findings allow us to provide a "genealogic analysis" of spatialtheories, we can say that the "spatiality" of the being, in ancient periods and in the Greek language (periods of Homer, Epicurus, Plato and Aristotle) have been conceived and understood by using three fundamental concepts, such as "kenon", "chora", and "topos". All three of these terms form the basis for theorizationof the "spatialities" of the beingin the ancient period, so that the human of this period, according to his distance relationships, uses the term "kenon" referring to the description of empty space; "chora" (chorography) to refer to the contents in the "kenon" such as regions and countries, and "topos" (topography) to refer to smaller portions of the "chora" such as places and locations Casey [6]; Algra [7]; Cresswell[8] and [9]. From the genealogic view, the distancing of human being(human existence spatiality) based on above three concepts in fact have been an attempt to overcome the being conditionin the cosmos(in form of interfere and practical/representational dealings with the earth) andfind meaning and order in it Bonnett [10]. The spatial understanding of this period has associated by epic, myth and poetic to representation and expression ofspatialities of being which for example can be found in Homer's works Dueck [11].

After the above period, Eratosthenes, the chairman of the library and museum of Alexandria (195-276 BC), Ptolemy, a disciple of Eratosthenes in Alexandria (168-90BC) -both as the protagonists of the mathematical/cartographic geography tradition- and Strabo (64BC-24AC) as a continuation of the Herodotus's textual geography, chorography and topography tradition (485-425BC) at the beginning of the Roman Empire, used the term "Geography" to define the operation of acquiring lore of the spatial aspects of Geo-human relations. In fact, they considered the spatialities of the being based on the Ptolemaic spatial order as a threefold hierarchy: Cosmography represented the totality of a spherical cosmos, geography provided geometrically exact images of the earth's spherical surface and its major divisions, and chorography pictured the form and character of localized spaces and places.So, Geography has conventionally been distinguished from cosmography and chorography because of its attention to such patterns as opposed to astronomical and local spatial representations, respectively Cosgrove[12](Figure 1).

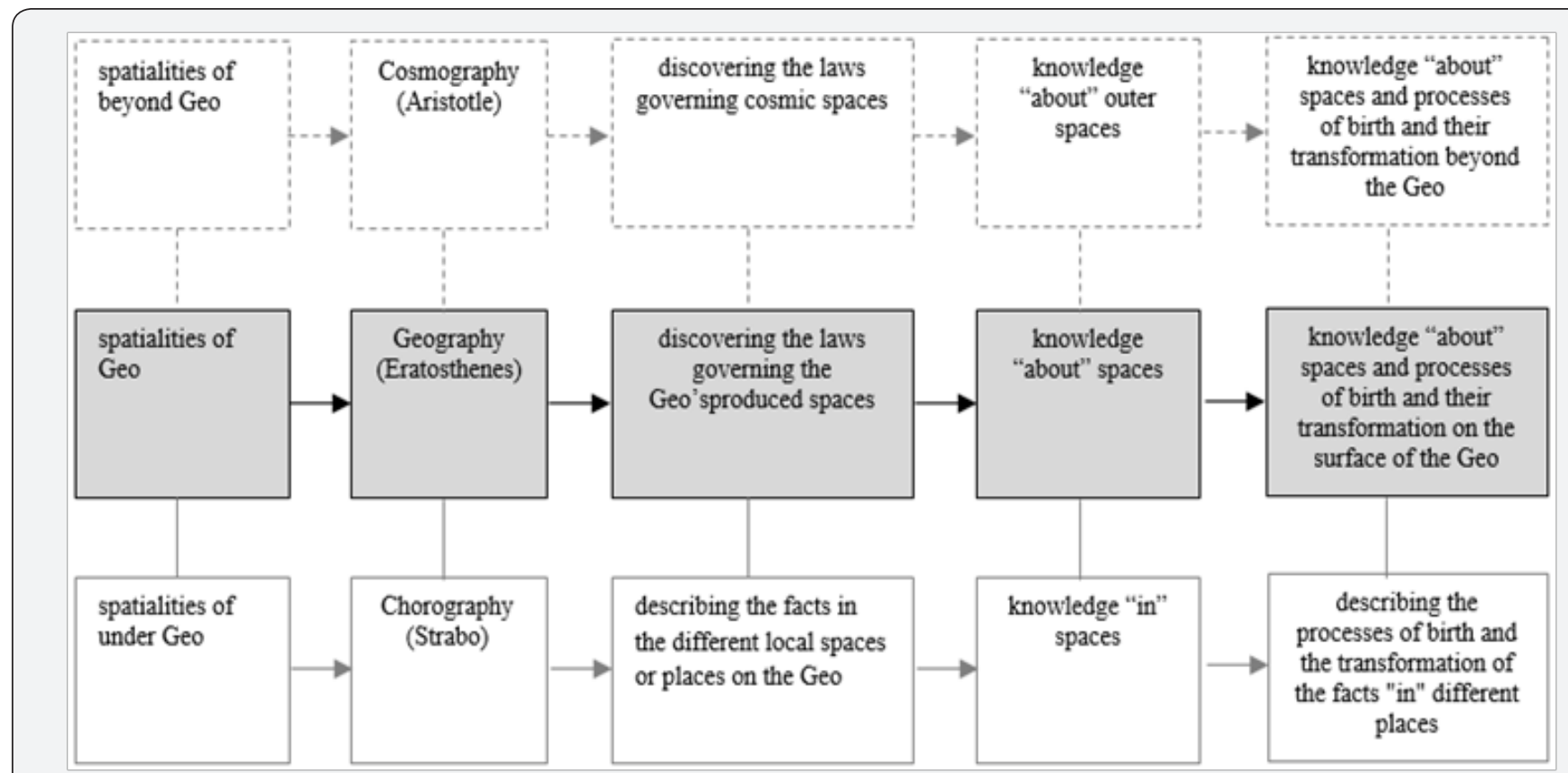

Figure 1: Position of geography in similar sciences based on Ptolemaic spatial order(Source, writer's elaboration). 
Contrary to Chorography which has focused on the describing and mapping the characteristics of specific local-scale locations, or Cosmography that focuses on outer spaces beyond the earth, Geography has concerned to the explaining and mapping human interactions with Geo which described into ground-level spaces, and is defined as a different act of Chorography and Cosmography. The birth of Geographyscience in a particular period,has been the result of the transition from the "celestial spatiality" - based on metaphorical and symbolic understanding - towards "terrestrialspatiality" - based on empirical and geometric understanding Cosgrove [12], Livingstone [13]. From now on, the geographer is the person who deals with the human interactions with the Geo based on certain geometries and specific spatial patterns.That Geography is a science based on "graphy" (survey), from the perspective of linguistics, is a very important point, which in fact illuminates and reflects the focus of this science on the "spatialities" of the Geo-human relationsand it was distinct from both exploring (travel around the earth) and the chorography (just a list of places with their characteristics). It means that geographers from the very beginning need to use the spatial vocabularies, mapping tools and graphic languages to representtheir lore, and today they are called "production of spatial knowledge" of the Geo-human relations. In terms of genealogy, appearance of the term "Geo" as the basic concept and subject matter for a science called "geography" in this period, must be taken into account in the light of the evolution of human civilization (e.g. move away from celestial spatiality to the terrestrial sphere) and the exacerbation of "cartographic anxiety" Gregory [14] via territorial encounters and expansion of empires, as well as stimulating the curiosity of human, in determining the scope and boundaries of territories and the discovery of new lands or worlds on Geo.

Spatialitiesof the Geo-human relationsin the Middle Ageswere tied with a sacred perception of Geo (Emblematic Geo and the place of transition that its mysteries must be discovered by human).Works of Muslim geographers (such as al-Idrisi (1100-1165), al-Maqdisi (1146-1203), Ibn-Battuta (1304-1369) and Ibn-Khaldun (1332-1406)until the period of geographic explorations and renaissance (such as Bacon, Descartes, Varenius, Humboldt period) have played important roles in diffusion of geography knowledge. (Unfortunately, little is known today about the contributions to geography knowledge made by scholars who lived and worked between the relatively well documented world of the Greeks and the Romans like Persian, Chinese and Indian territories). In the Renaissance, spatialities of the Geo-human relationsare more depicted in the form of "utopias", which is a kind of imaginary Geo that served as social and moral prisms for viewing the actual one Cosgrove [12]:94.As Harley and Woodward shown in their three-volume books about cartography history, we find that in the two Ancient and the Renaissance periods, the greatest efforts were made to estimate and map the "Geo" surface and the construction of geographic spheres. Because maps were the main step in the appropriation of territory in the New World into a rational and controllable structure[14-17].

After the Renaissance, Immanuel Kant (1804-1774), as lecture of geography at the university of Königsberg in East Prussia (part of today's Germany), although has conceptualized the "Geo" based on Newton's abstract concept of "space"but,in practice, he had interpreted geography as a chorography discipline. "Kant used the word 'chorographic', meaning descriptive, to describe geography" Werlen[18]2.In Kantian classification of sciences, geography studies the world in relation to space (in terms of localized spaces and places) and history in relation to time. In Kant's philosophy, space in its absolute sensewas not something objective, real, substance or a relation, but it is subjective and ideal and proceeds from the nature of the mind (sensorium) and condition of knowledge.In other worlds, Newton's treatment of space as fixed grids and containers in which events are located, and Kant's view that cognisance of events and objects in time and space is inherent to human perception. However, the geographic space, based on his interpretation, is not presented as an analytical category to the geographicity of Geo-human relations(as it stands today) but according to the conditions in this period, geography in his view and in focusing on geographicities, attends more to the localized spaces, places andregions (and consequently as apropaedeutic,descriptive or taxonomic discipline). So, geographyin terms of Hettner's and Hartshorne's chorological interpretation (see Hartshorne 1958b), accepted Kant's distinction between geography and history as the physical classification and study of phenomena belonging together in the same space and same time, respectively, and subordinated the former to the latter.

Given the Kantian classification of sciences, the task of geography is in practice, first of all, to discover, collect and synthesize the experimental facts of different regions of the Geo for analytical sciences (in fact his philosophical research). In terms of a genealogic analysis, the importance and significance of the concept of "region" in the Renaissance period is necessary (in fact prefer chorography instead of geography), given the increasing sensitivity of humans (especially the West World) to the discovery of other sources in other parts of the Geo. This is often explained with the aim of using those resources to expand the territorial power (e, g. Europe located itself at the centre of an imaginative grid that positioned all other continents in subordinate spaces). However, the most important difference between this period and the earlier period is that in the discourse of this period, the western human looks at the "other" geography (East and South world) as a source for self-understanding Said [19].

By increasing the level of "modernization" and the consolidation of modernism ideology in the world and looking at the evolution of the nature of geographic knowledge into this process, we can identify a transition fromchorographic 
interpretation of geography to the systematic understanding of geography. For some geographers,Modernity has been looked at as a project of spatial standardization, shaped by the conception of spatiality as a universal, measurable and divisible entity and making location and distance key markers of difference between places Crang[20](Table 1).Chorographic interpretation of geography represents the recording and accumulation of facts about various phenomena and their spatial configurations arising from human-nature interactions ("capes-and-bays" image of geography). This kind of knowledge, in general, is the basis of descriptive geographical knowledge. In this approach, space is not in itself a subject matter and an explanatory factor, but merely an absolute, independent or background factor. But, systematic understanding of geography involves recognition and expansion of the relationships between the geographical basic principles (such as distance, direction, orientation, distribution, patterns, organization, territoriality, geographic correlations, etc.) and the advanced concepts derived from such basic principles to achieve theory and generalization ("scientific" image of geography) Golledge [21].

Table 1: Geneology of geographical spirit of times.

\begin{tabular}{|c|c|c|c|c|}
\hline $\begin{array}{l}\text { Geo as a consumer good/ } \\
\text { commodity }\end{array}$ & Geo as a ordered system & $\begin{array}{c}\text { Geo as layers of mysteries, } \\
\text { metaphors and sacred } \\
\text { areas }\end{array}$ & Geo as a live dentity & $\begin{array}{l}\text { The types of human } \\
\text { Interactions with the Geo }\end{array}$ \\
\hline Societal & Anthropocentric & Theological & Magical & Types of Spatialities \\
\hline $\begin{array}{c}\text { Understanding the } \\
\text { processes of socially } \\
\text { construction of spatialities } \\
\text { of Geo-human relations }\end{array}$ & $\begin{array}{l}\text { Discovering the laws } \\
\text { governing spatialities of } \\
\text { Geo-human relations }\end{array}$ & $\begin{array}{l}\text { Decryption of spatialities } \\
\text { of Geo-human relations }\end{array}$ & $\begin{array}{l}\text { Harmony with spatialities } \\
\text { of Geo-human relations }\end{array}$ & $\begin{array}{c}\text { Focal points of Geographic } \\
\text { Theories }\end{array}$ \\
\hline Post-modern & Modern $\rightarrow$ & Middle Ages $\rightarrow$ & Ancient $\rightarrow$ & Periods \\
\hline
\end{tabular}

At the time of the theoretical revolution in Geography in 1950s, Geography was read as a "spatial science". Understanding geography as a spatial science is the official starting point for addressing the spatial aspects of the Geo-human relations with the goal of producing knowledge about spatial interactions on the surface of the Geo as a unit space. It is not surprising, in this period, that Frederick Schaefer argued that "geography has to be conceived as the science concerned with the formulation of the laws governing the spatial distribution of certain features on the surface of the earth" Schaefer [22]. For Schaefer and his advocators, this meant explicitly recasting the implicit ontology of space by using the language, principles, laws, reasoning and representation of science. Here, spatiality was defined and understood in absolute terms as a geometrical system of organization (usually Euclidean geometry with $\mathrm{x}, \mathrm{y}$, and $\mathrm{z}$ dimensions and Newtonian physics) within which people and objects are located and move through. Spatial processes operating within this space could be measured objectively and scientifically, and then analyzed using quantitative techniques and spatial statistics Haggett [23]; Chorley andHaggett, [24]; Morrill [25]; Abler, Adams and Gould [26](Table 2).

Table 2: Chorographic interpretation of geography and systematic understanding of geography.

\begin{tabular}{|c|c|c|}
\hline Chorographic & Transition & Systematic \\
\hline phenomenal & $\rightarrow$ & intellectual \\
\hline accumulation facts & $\rightarrow$ & recognition relations \\
\hline declaration & $\rightarrow$ & explanation \\
\hline what's where? & $\rightarrow$ & why and how? \\
\hline Inductive & $\rightarrow$ & deductive \\
\hline facts finding & $\rightarrow$ & laws finding \\
\hline localized spaces & $\rightarrow$ & abstracted spaces \\
\hline
\end{tabular}

From the genealogic perspective, the Newtonian spatiality project as the main geographic view to Geo-human relationsdescription should be understood in light of the wider development of the dominant capitalist system and the positivism/modernism ideology of this period reaches its peak by rationalization and social engineering after World War II. So that positivism's discourse in geography science can reproduce itself in the forms of commodifying/consuming space with new spatial distances between worker and product, producer and consumer, city and country, knowledge and the conditions of its making, viewer and object, self and other, and representation and reality, also new spaces of knowledge like ocean-going ships, plantations, laboratories, censuses, accounting systems, museums, maps, prisons, department stores, industrial districts, railways, telegraphs and tourism Agnew andLivingstone [27].

Understanding geography as a spatial science, after a definitive break from chorographic interpretation of geography, persists in contemporary literature and discourse and changes the old controversy in this science. Is geography a science that deals with the production of knowledge "in" space, whose mission is to provide an organized combination of knowledge about various phenomena "in" space, and space is understood as a backgroundor is it a science that produces knowledge "about" spatialities whose task is to provide the spatial causalities, in which space is perceived as an agency to the occurringvarious phenomena (as discussed by Richard Hartshorne, Carl Sauer, Frederick Schaefer, David Harvey, Brian Berry, Doreen Massey, Richard Morrill and others about the nature and philosophy of geography). This breakleadsthe focus of this science on the new controversy, namely, absolute space (e.g. Newton's space), relative space (e.g. Einstein's space), relational space (e.g. Leibniz's space), and, more recently, often affected by the social 
constructivist approach; material-physical space (experimental space based on tangible things), conceptual-subjective space (representation of space based on ideas) and social-lived space (spaces of representation based on social actions); or space as a precondition, mediation and outcome of social actions. While they are of course closely interrelated.

This shifts the almost complete geographic focus to the production of knowledge about spatialities and Geo-human relationsdescriptions based on and through the principles of spatial knowledge, which leads to the formation of a ground for a more complex conflict with the title spatiality in contemporary geography literature. Understanding space as a constructed, situated, relational and becoming entity (or space as a verb) is opposed to the understanding of space as a preexperience, independent, absolute, constant, background and neutral entity (or space as a noun). From a genealogic view, this radical change is strongly influenced by the failure in the ideals claimed by the modernist discourse and the formation of post-positivist epistemological sensitivities and the critique of the Enlightenment's ideas about reason and science Curry[28]. Based on such a reading of the evolution of concepts in geography, it can be said that the controversy of the definition of geography with the aim of determining its nature as a science in the contemporary era, predominantly, focuses on Enlightenment and the choice between that type of geography as knowledge in space to describe the Geo (what's where?); or, the kind of geography that has its main task of producing knowledge about spatialities for explaining the Geo (why and how?).

It is necessary to mention that the role of the spatialities as causal factors within geographic theories has generated considerable debate.In this line, the extreme positions taken up by those who ascribe no independent role for space in the production of social phenomena (such as social determinism), and others (such as spatial determinism), who considered spatial laws to exercise a deterministic influence on patterns of human activity. "Just as most locational studies have failed to relate geographical changes to wider social relations, so have most studies of social relations ignored geography. Conceptual work in economics and sociology frequently proceeds as though the world existed on the head of a pin - as though it were distanceless and spatially undifferentiated" Massey [29,30].

Following the radical critique of the positivist paradigm in human geography, it has generally been accepted that space is socially constructed. This, however, does not eliminate the relevance of the spatial perspective but rather embeds it within a wider concept of socio-spatial relations. That means not only the spatial is socially constructed but also the social is spatially constructed too.As Massey [29,30]points out, "just as there are no purely spatial processes, neither are there any non-spatial social processes". This notion of a reciprocal relationship between space and society is taken up in Soja's[31] concept of the "socio-spatial dialectic", while Pred[32]has attempted to theorize the relationship in terms of a structuration perspective Pacione [33].Under this view, one might arguethat concepts such as place, territory, landscape, environment, region, etc. represent a distinctive types of spatialities which are defined by or constructed in terms of the experiences of human'sbeing on the Geo as a geographical space. Also, under these conditionsspace likely to become place; place is likely to become territory; territory is likely to become neighborhood and so on, with a variety of spatial features such as diffusion, dispersion, orientation, hierarchization, contagion, segregation, and centrality Harvey [34].

No serious attention has ever been taken to geographic theories of cognitions and actions prior to the "geographical turn "or "spatial turn" in philosophy, literature, and humanities/ social sciences (with the advent of some of the 1960s Parisians, including Foucault, Deleuze and Lefebvre, and the revival and expansion of their thought after the 1980s).Space is taken only based on natural and mathematical sciences, as external, dead, static, neutral, absolute, and constant. So, what matters is merely the change and dynamism in the temporal (and social) dimension that is the basis of "historicism" (framing of our studies around single Histories like Modernization or Progress). But from this period onwards, spatialities have become the basic factor in the causal/actant theorizations GulsonandSymes [35]; Warf and Arias, The growing currency of geographic theories is closely linked to the recognition of spatialities' key role in the processes by which people reconstruct their understandings of the world. Putting spatiality first in looking at the world is, in this sense, an exploration of new grounds and a search for new insights Soja[36]. Moreover, spatial causality has been the primary forces behind the transformations of world as well as all forms of societal development Massey [37] and whereby "making space for space" Finnegan[38] and advent a new "Geographicalism".

The main concern in "Geographicalism" is the spatiality of scientific knowledge. Therefore, the "geographical turn" is a kind of revealing of the infusion process of spatial vocabulary and languages into historical and philosophical accounts of scientific knowledge (although in this period we also see the importance of the "sociology of science" in the philosophy and history of science, this approach is insufficient to understand other types of scientific dynamics such as science in situ orscience in motion). A central guiding assumption that often sustains and directs these conversations has been that space need is not thought of as a container or backdrop for social life. This is a view often described as an abstract Cartesian notion of geometric spacebut rather, it is considered as an active ingredient in social and cultural life or an inescapable (which is not say uniform) mode of existence.This relational view of space has provided grounds for integrating more fully geographical/historical/sociological accounts of science and has been widely adopted by scholars explicitly concerned with developing a historical geography of scientific knowledge Finnegan [38]. 


\section{Representations of Geo-Human Relations in Modern Geographic Theories}

Representations in geography as depictions of produced spatialities from Geo-human relations do more than reflect reality. They bring not only the world into being, but also guides to action on the social life Wood [39]; pickles [40]. Genealogy of produced spatialities from Geo-human relations in the thoughts and actions of geographers show that the depictions has always been done by using some of the representations Johnston and Sidaway [41];Couper [42]; Cox [43];Cresswell [9];Nayak andJeffrey [44]; Holt-Jensen [45]; Martin [46]; Pickles [40]; Peet [47]; Unwin [48]; Livingstone [13]; Stoddart [49], among other. For example, before the modern era, the spatialities of Geo-human relations was based on the metaphors of poetic, philosophical, religious, idealistic and symbolic in a special worldview Cosgrove[12], and with the beginning of the modern period, there have been used the mosaic, organic, arena, stage, mechanical, systemic, network and flow metaphors and in a special scientific discourse. These metaphors are intended to represent the spatialities of the Geo-human relations influenced by "worldviews" (more in the old period), and then "scientific paradigms" (more in the new period), which in the different period overcome the thoughts and actions of geographers.

From the late nineteenth and early twentieth century, the norm of being or not being scientific determined the scope and boundaries of various geographic readings and representations of Geo-human relations Claval[50]. As noted earlier, the scientific norm of geographical understanding and interpretation of the Geo-human relations in the contemporary period considers geographicity to be equivalent to spatiality; therefore, in the contemporary period, the focus of attention in geography to understand the dynamics of the second nature (produced spatialities) is based on socio-spatial actions (space as a dynamic agency not just as a static background).

One of the first scientific readings of geographic dynamics, based on the concept of socio-spatial actions in the modern geographic period (late nineteenth and early twentieth century), which often has an experimental and inductive nature, reads Geo as a "nature" in the deterministic and Darwinian concepts,Geo as an "environment" in possibilitism, and Geo as a "unique regions" in the Kantian's perception that we and things are placed in it. In the reading of Geo as nature, that kind of spatial action is considered in which human is considered to be the product of nature and a natural selection. In the reading of Geo as the environment, that kind of spatial action is considered in which human is perceived by his interactions with his environment, and in the reading of Geo asunique regionsthat kind of spatial action is considered in which humans and nature form a variety of syntheses, unifications and harmonics compositions. The common point of all these three readings is that spatial action is generally explained based on the "spatial forms" that remains on the Geo surface.
With the critique of experimental and physical readings to Geo, a Newtonian reading of Geo in geography is formed to transform geography into a scientific and theoretical discipline (a shift from an inductive to the deductive methodology in geography).It quickly became the bedrock of the "theoretical revolution" and then the "quantitative revolution" of the 1950s in geography Burton [51]; Bunge [52]. In this course, Geo is described as isotropic plain, fixed geometry or space as "metric distance" which is subject to Newtonian laws (for example, gravity laws and friction of distance). This kind of unit space, in fact, is a theoretical space, based on absolute, fixed and irreducible intervals, as well as a distinct, computable, and estimated quantity in a quantitative manner, which, as a container, we and objects are located within it. Most spatial analyses that use concepts such as distribution, dispersion, proximity, relation, accessibility, clustering, scale, and exposure are involved in estimating the metric distance factor. The metric distance factor for the geography of the 1950s is so important that even Watson calls geography a "distance science" Watson [53]. The metric distance factor in this reading is based on two basic principles of space: (1) the maximum use and profit from each piece of land, (2) the achievement of the maximum possible volume of interaction with the least possible cost, the basis for structural theorization and the spatial organization Morrill [25]; Abler, Adams and Gould [26]; Amedeo and Golledge [54]; Haggett et al. [55].

Table 3: Types of readings from the "Geo" in the modern geographic theories.

\begin{tabular}{|c|c|c|}
\hline $\begin{array}{l}\text { Geographic } \\
\text { Theories }\end{array}$ & $\begin{array}{l}\text { Type of readings from the } \\
\text { "geo" }\end{array}$ & $\begin{array}{c}\text { Nature and } \\
\text { orientations }\end{array}$ \\
\hline $\begin{array}{l}\text { determinist } \\
\text { geography }\end{array}$ & Geo as nature & \multirow{3}{*}{$\begin{array}{c}\text { a priori } \\
\text { container; } \\
\text { form-oriented } \\
\text { spatial analysis }\end{array}$} \\
\hline $\begin{array}{l}\text { regional } \\
\text { geography }\end{array}$ & $\begin{array}{l}\text { Geo as natural and built } \\
\text { environments/ landscapes }\end{array}$ & \\
\hline $\begin{array}{l}\text { positivist } \\
\text { geography }\end{array}$ & $\begin{array}{l}\text { Geo as absolute and relative } \\
\text { space }\end{array}$ & \\
\hline $\begin{array}{l}\text { behavioral } \\
\text { and cognitive } \\
\text { geography }\end{array}$ & $\begin{array}{l}\text { Geo as conceptual spaces/ } \\
\text { mental environments }\end{array}$ & \multirow{4}{*}{$\begin{array}{l}\text { constructed } \\
\text { category; } \\
\text { process- } \\
\text { oriented } \\
\text { spatial analysis }\end{array}$} \\
\hline $\begin{array}{l}\text { humanistic } \\
\text { geography }\end{array}$ & $\begin{array}{c}\text { Geo as experimental and } \\
\text { societal places }\end{array}$ & \\
\hline $\begin{array}{l}\text { structural, } \\
\text { neo-Marxist } \\
\text { and feminist } \\
\text { geography }\end{array}$ & $\begin{array}{l}\text { Geo as socially produced, } \\
\text { consumed and gendered } \\
\text { spatialities }\end{array}$ & \\
\hline $\begin{array}{c}\text { critical, } \\
\text { postmodern, } \\
\text { post-colonial and } \\
\text { post-structural } \\
\text { geography }\end{array}$ & $\begin{array}{l}\text { Geo as difference and } \\
\text { discourse space; stage and } \\
\text { tools of the forces of power }\end{array}$ & \\
\hline $\begin{array}{l}\text { actor-network, } \\
\text { non- } \\
\text { representational } \\
\text { and more- } \\
\text { than-human } \\
\text { geographies }\end{array}$ & $\begin{array}{l}\text { Geo as hybrid, flow, becoming, } \\
\text { relational, performance and } \\
\text { embeddedness natures, } \\
\text { environments and spatialities }\end{array}$ & \\
\hline
\end{tabular}


In a social-based spatial interaction, the absolute space, with metric distances, can be a monopoly of the property of a person on earth and other things of a certain realm, such as states, administrative units, urban plans, and urban networks. Absolute spaces can also be conceptualized as power containers. The space of this kind is clearly distinct from time. Spatial order is another important issue in this type of space. It shows its absolute time in a linear path that continues indefinitely. From this perspective, therefore, history is interpreted as something distinct from geography Harvey [34].(Table 3). However, with a quick critique of the absolute understanding of space from the relative space approach, a space as "function" (relative distance) reads. In this reading, space is not a container or absolute coordinate already existing, to be based solely on vertical relationships, but it is a product of horizontal relationships between things. When the relationship between things changes, space also changes Cox [9]. According to this new reading, the distance factor is not just a constant and Euclidean metric, but rather it is a product of a complex set of perceptions and social feelings. For example, in this type of understanding of space, distance is considered based on its function, such as time interval, economic distance or cost, perceptual distance or cognitive distance and social distance Unwin [48].

Relative space is, in essence, a space of processes and movement. Accordingly, space cannot be understood in isolation from time, history and geography. All geography is historical geography, and all history is geographical history. The relative space of transportation relations, and the flow of goods and money, is very different from the absolute spaces of personal property. We can produce completely different maps of relative locations by differentiating between estimated distances based on cost or time, or automobile, bicycle or pedestrian Harvey [56]. We all have faced with differential frictions on the earth's surface, so that the shortest distance (estimated in terms of time, cost, and energy) between the two points is not necessarily the direct distance between them, but it depends on time, cost or energy consumption. In addition, the point of view of the observer plays an essential role in shaping such an approach to space.

This relativeness does not necessarily diminish or eliminate the power and capacity of discretion or control, but it implies that we, in order to explain certain phenomena and processes, need certain spatial laws. In such a case, estimation and computational complexity become more complicated, so that for each of them, concepts, languages and different representation methods (for example, a variety of geometries) can be selected. In fact, a space framework, depending on what is being taken and by whom, can be different. Einstein compiles this argument so that all forms of estimation depend on the reference framework of the observer. However, until now, phenomena and processes are still within the existing space and time or are affected by space and time(Table 4).However, in the "relational" space, processes themselves are the producers of their own space and time. Contrary to the absolute and relative attitude to space, from the point of view of relational space, matters and processes are not placed in it or even affected by space and time, but space and time are the materials and processes. It is therefore impossible to separate space from time. They are spacetime (without any line in between)(Table 5).

Table 4: Main spatial topologies of Geo in geographic theories.

\begin{tabular}{|c|c|c|c|c|c|c|}
\hline $\begin{array}{c}\text { Topological } \\
\text { Presupposition }\end{array}$ & $\begin{array}{c}\text { absolute } \\
\text { coordinates }\end{array}$ & $\begin{array}{c}\text { relative } \\
\text { coordinates }\end{array}$ & bounded regions & networks & flows & virtuals \\
\hline $\begin{array}{c}\text { Sample Usage in } \\
\text { Geography }\end{array}$ & $\begin{array}{l}\text { locational- } \\
\text { spatial analysis } \\
\text { (according } \\
\text { to the type of } \\
\text { reference metric } \\
\text { coordinates) }\end{array}$ & $\begin{array}{l}\text { analysis of } \\
\text { relative distances } \\
\text { (time, cost, } \\
\text { psychological) }\end{array}$ & $\begin{array}{l}\text { analysis of the } \\
\text { boundaries and } \\
\text { spatial domains } \\
\text { (ownership, } \\
\text { domination and } \\
\text { enforcement } \\
\text { of power and } \\
\text { energy) }\end{array}$ & $\begin{array}{l}\text { network analysis } \\
\text { (simple, feedback, } \\
\text { self- organized, } \\
\text { complex) }\end{array}$ & $\begin{array}{l}\text { flow analysis } \\
\text { (human, } \\
\text { commodity, } \\
\text { money, and } \\
\text { information) }\end{array}$ & $\begin{array}{c}\text { cybernetic } \\
\text { analysis and } \\
\text { virtual spaces }\end{array}$ \\
\hline
\end{tabular}

Table 5: Main spatial binariesof Geo in geographic theories.

\begin{tabular}{|c|c|c|}
\hline Space Aspects & Absolute / relative & Relational \\
\hline ontology & space as objective & space as perspective \\
\hline methodology & atomistic, individualistic & critical realist/ poststructuralist \\
\hline epistemology & neo-positivist/ critical rationalist & space as a relation, social action, process and becoming \\
\hline subject & space as an objective consequence actions & deconstruct the principles and laws governing inspatialities \\
\hline object & discover of spatial laws & \\
\hline
\end{tabular}

In the relational view, various and even disparate effects flow from one place to another. The nature of phenomena here means something completely different from the sense that we have of them in absolute space, and even in relative space-time, because

the nature of the phenomena here turned into something open, fluid, multiple, and indefinite. In short, entities are immaterial but real, and this depends, first, on the state of our being from one moment to the next. In fact, relational concepts take us to a 
point in which mathematics, ethics, and art are interconnected, interact and integrate together and creativity grows Harvey [34]; Thrift [57]; Massey [37]; Agnew [27]; Claval [50].

The above changes by 1970s provide the context in which behavioral, humanistic, radical and critical geographers begin to criticize Newtonian representations of Geo as a background and something neutral in analyzing the spatial actions. From then on, Geo in general, reads not as a Newtonian container or plain (with absolute distance or relative distances) and neutral in the background, but as an experienced nature, environment and space, along with the agency that its existence and nature are not independent of human and social relations or actions Werlen [18]. In short, nature, environment and spaceare not standing there but are a social construct. This kind of representation of nature, environment and space, instead of the concept of a priori nature, environment or Newtonian plain, places the concept of society or "societal" in the focus of spatial actions, and interprets spatiality based on social relationships and ruleswhich is said a shift from form-oriented spatial analysis to process-oriented spatial analysis. Therefore, it is natural that geographers from this period onwards will be strongly shifted to the broad development of social theories.

In representation of Geo as experienced environments or sociallycontractivespatialities, several approaches can be distinguished:

a) Representation of Geo as "psychological environment" in the thoughts of behavioral and cognitive geography Cox andGolledge [58],GolledgeandStimson [59].

b) Representation of Geo as "experimental and societalenvironment/place" in the thoughts of humanistic geography and time geography Tuan [60,61]; Relph [62]; Buttimer [63]; Leyand Samuels [64];Hagerstrand [65].

c) Representation of Geo as "socially produced/ consumedspatialities" in the structural, neo-Marxist and feminist geography views Harvey [66,67]; Smith [68]; Massey [29,30]; Pred [32]; Monk andHanson[69]; Women andGeography Study Group [70], Corbridge [71]; Domosh[72]; Storper[73].

Table 6: Types of spatial dominant epistemological approachesingeographic theories.

\begin{tabular}{|c|c|c|c|}
\hline \multirow{4}{*}{ Types of spaces } & physical space & mental space & social space \\
\hline & materialities & meanings & practices \\
\hline & absolute space & relative space & relational space \\
\hline & organic space & conceptual space & symbolic space \\
\hline \multirow{2}{*}{ Epistemological approach } & space as a container & space as a function & space as a relation \\
\hline & $\begin{array}{c}\text { construct and experience spaces } \\
\text { as material artifacts }\end{array}$ & $\begin{array}{c}\text { representations of spaces in } \\
\text { discourses }\end{array}$ & use of spaces as representations \\
\hline
\end{tabular}

d) Representation of Geo as "stage and mediator of the power forces and difference" in critical, postmodern, postcolonial and post-structural geography approaches Soja [36,74]; Jacobs [75]; Cresswell [76]; Doel [77]; Dear [78]; Blunt and McEwan [79]; Murdoch [80].

e) Representation of Geo as "hybrid, flow, becoming, performance and embeddedness natures/environments/ spatialities" inview of theactor-network, non-representational and more-than-human geographiesMurdoch [81]; Law andHassard [82]; Gregson [83]; Whatmore[84]; Thrift 2008 [85]; Anderson andHarrison [86]; Greenhough [87]; Vannini [88]; Boyd [89].

The real nature and orientation of all such representations of Geo-human relationsis based on the experiences and socialbased spatial actions. Geographers today have come to the conclusion that understanding each type of representations requires placing them in the context of social action. And "data [spatial data] are always theory-laden and theories are always politics- and opinion-laden, articulated on the basis of differing assumptions and presumptions about how the world works, and how it could work better" Leitner and Sheppard [90].This means that representation of Geo-human relations is understood in contemporary geography as a biased and relational construction rather than beingneutral and container or independent of the events Simonsen [91]; Kitchinand Valentine [2]; Warf [92]. In this period, natural/physical geography continues to study of Geo asnatural environments along with tendencies towards theevolutionist, positivist, pragmatist and (critical) realist approach in science, though recent philosophical discourse has been centered mainly on the issue of methodology not ontology Haines-Young and Petch [93]; Rhoads and Thorn [94]; Rhoads [95]; Slaymaker [96]; Inkpen\& Wilson [97](Tables 6-10).Different types of spatial representations of Geo-human relations in geography theories are presented in the following tables based of various typologies and different divisions. This should, of course, not be regarded as a comprehensive list of the possible representations of spatialities; it simply identifies some of the dominant representations that have relevance to this discussion. 


\section{International Journal of Environmental Sciences \& Natural Resources}

Table 7: Types of spatial dominant methodological approachesingeographic theories.

\begin{tabular}{|c|c|c|c|c|c|}
\hline $\begin{array}{c}\text { Spatial } \\
\text { understanding }\end{array}$ & $\begin{array}{c}\text { Observation and } \\
\text { categorization } \\
\text { of the facts and } \\
\text { phenomena in } \\
\text { space }\end{array}$ & $\begin{array}{c}\text { Understanding } \\
\text { and defining space } \\
\text { as function (e.g. } \\
\text { environment and } \\
\text { distance) }\end{array}$ & $\begin{array}{c}\text { Understanding } \\
\text { space based on } \\
\text { the basic logic } \\
\text { of relationships } \\
\text { governing society }\end{array}$ & $\begin{array}{c}\text { Understanding } \\
\text { space based } \\
\text { on different } \\
\text { experiences of } \\
\text { individuals }\end{array}$ & $\begin{array}{c}\text { Understanding } \\
\text { space as social } \\
\text { construction }\end{array}$ \\
$\begin{array}{c}\text { Methodological } \\
\text { approach }\end{array}$ & $\begin{array}{c}\text { experiential and } \\
\text { inductive }\end{array}$ & $\begin{array}{c}\text { theoretical and } \\
\text { on doing and } \\
\text { engaging in the } \\
\text { flow and context }\end{array}$ & $\begin{array}{c}\text { structural and } \\
\text { critical }\end{array}$ & $\begin{array}{c}\text { phenomenology } \\
\text { and hermeneutics }\end{array}$ & $\begin{array}{c}\text { situated and } \\
\text { constructivist }\end{array}$ \\
performance
\end{tabular}

Table 8: Types of spatial dominant analytical approaches in geographic theories.

\begin{tabular}{|c|c|c|c|}
\hline Spatial Actions & production of spatialities & regulation of spatialities & consumption of spatialities \\
\hline Analytical Approach & economic-based & policy-based & culture-based \\
\hline
\end{tabular}

Table 9: Types of relations between space and societyin geographic knowledge.

\begin{tabular}{|c|c|c|c|}
\hline Types of Relations & Space reflects social actions & Space constructs social actions & $\begin{array}{c}\text { Space is a means of resistance and } \\
\text { celebration }\end{array}$ \\
\hline Space Role & Passive & Active & Intermediate \\
\hline
\end{tabular}

Table 10: Types of representations of spacein social theories.

\begin{tabular}{|c|c|c|c|}
\hline Representation of space & space as material environment & space as a difference & space as social spatiality \\
\hline Theories samples & $\begin{array}{c}\text { environmentalism, 'traditional' } \\
\text { regional geography, landscape } \\
\text { morphology }\end{array}$ & $\begin{array}{c}\text { critical realism, feminism, } \\
\text { postmodernism, post- } \\
\text { structuralism }\end{array}$ & $\begin{array}{c}\text { production of space, postmodernism, } \\
\text { historical-geographical materialism, } \\
\text { feminism, phenomenology, } \\
\text { constructivism }\end{array}$ \\
\hline
\end{tabular}

It should be noted that all the various representationsofspatialities presented in the history of geography are closely related to the evolution of scientific paradigms (for example, the evolutionary paradigm, positivism, and post-positivism). In other words, in line with the general developments in the philosophy of science, geographers have also tried to update themselveswith regard to the paradigm or discourse governing the scientific and academic community and various types of representations of spatialitiesand, consequently, the production of spatial knowledge for explaining spatial actions or solutions Hartshorne, [98,99]; Harvey [34]; Thrift [57]; Massey [37]; Agnew [27]; Claval[50].Now, we might argue that the contemporary history of geography, especially human geography, has been the history of various representations of Geo-human interaction's spatialities in the sense of anthropogenic-based spatial actions and this has been at the center of concerns in this science. Therefore, given the above developments in understanding of spatialities in contemporary geography and its link with social theory, it is entirely natural that most of the concerns of today's geographers focus on spatial actions in the sense of its constructive case[100-120].

\section{Concluding Remarks}

Geographers have always sought new theorizationsabout spatialities of Geo-human interactions. Such efforts have led geography to be always confronted with new theories. Obviously, the concern about any of these theories is heavily dependent on the context in which geography lies. If we accept that every science has its own specific theories, geography will also have its own specific theories. In fact, any science is looking for theories that are most relevant to it. The choice of theories in any science, while somewhat influenced by the context, also depends on the subject and nature of that science. This paper has attempted to show that all of the various theories in geography had a distinct feature that can be considered not only as a criterion for the construction of particular theories in this science, but also the purification of geographical theories of non-geographical theories.It has been explained here that all geographical theories are used to explain the spatialities of Geo-human interactions. The focus of such theorieshas been on understanding the Geo as a "space" and the spatial dynamics of it. Such a special feature in geographical theories can serve as a basis for distinguishing between geographic theories in geography and similar theories in some other sciences whose nature and subject more or less deal with earth and space.

Therefore, if we accept that the theories developed in geography are the theories that have been used to explain the spatialities of Geo-human interactionsbased on the principle of distance relations (not just spatialities that do not necessarily relate to Geo-human interactions like Architecture and Physics and not just Geo-human interactionsregardless of their spatialities like Biology and Ecology); we can now present a genealogy on the transforms of theorizing of geography.When we look at the history of geography in this proposed framework, we can identify which theories are really geographical. It has the potential to integrate all the different trends in this science. It seems that we can solve a number of challenges and doubts in defining or introducing the position of geography in other sciences. The higher the value of this framework, the more is in the field of geography education or pedagogical purposes. Indeed, if students of geography are, from start, on the path of discovering "spatialities of Geo-human interactions" based on 
distance relationships and spatial causalities (the difference that spatiality makes by its role as agency and context), they can have a more systematic and coherent intellectual/mental system in the production of geographical knowledge.

Obviously, the production of geographical knowledge is much more complex today than before. Acquisition lore about the geographical spirit of times is just a starting point for a geographer. A geographer becomes aware of this in the first place as the geographical spirit governing a certain period. This geographical spirit of the time which depends on the way that humans interact with the Geo, use as a world-wide for geographical researches. Thus, geographers, given this initial awareness, are on the path to addressing the details of the spatialities contained therein on the various scales (from body to global). Obviously, when the geographical spirit of each period changes, the subject of geographical studies will also change accordingly.However, the production of such diverse geographical knowledge requires a variety of methods for representing. One can claim that in the humanities and social sciences, there is no science except geography in which representation of knowledge is so important. This means that the new theorizations in geography have always been accompanied by strong links with the discovery of new representations methods, because every geographical theory also requires appropriate methods and means of representationand visualisation methodologies(for example, different maps remain the most common tool in any geography study, and geographer are attentive to the stories told by maps). Geographers, depending on the type of theories which they choose in this science, phenomena that these theories explain and the tools they used to represent, will distinguish their own science from other sciences. One of the most useful conceptual frameworks for distinguishing geography from other sciences can be the idea of "spatialities of Geo-human interactions" which is theorized in this science in various ways. Therefore, geography will be what geographers do, or what they say they do.

\section{References}

1. Hubbard P, Kitchin R, Valentine G (2008) Key texts in human geography. Sage, London, UK.

2. Hubbard P, Kitchin R(2011) Key Thinkers on Space and Place ( $\left.2^{\text {nd }} E d n.\right) ;$ Sage, London, UK.

3. Shoorcheh M (2017) Geographical Schools: From Early to Contemporary, ( $\left.2^{\text {nd }} E d n.\right) ;$ Parham-Naghsh, Tehran, (Persian).

4. Shoorcheh M (2018) On the spatiality of geographic knowledge. Asian Geographer.

5. Mayhew RJ (2012) Geography's Genealogies: In: Handbook of Geographical Knowledge. J Agnew, D Livingstone (Eds.); Sage, London, UK, p. 21-38.

6. Casey ES (1997) The Fate of Place: A Philosophical History. University of California Press. Berkeley, CA.

7. Algra K (1994) Concepts of Space in Greek Thought. Leiden, Brill pp. $1-365$.

8. Cresswell T (2004) Place: A Short Introduction. Oxford, Blackwell.
9. Cresswell T (2013) Geographic thought: A critical introduction. Wiley-Blackwell.

10. Bonnett A (2008) What is geography? Sage publishers, London.

11. Dueck D (2012) Geograpnhy in Classical Antiquity. Cambridge University Press, Cambridge.

12. Cosgrove DE (2001) Apollo's eye: A cartographic genealogy of the earth in the western imagination. Baltimore: The Johns Hopkins University Press p. 13-331.

13. Livingstone D (1992) The Geographical Tradition: Episodes in the History of a Contested Enterprise. Oxford, Blackwell, UK.

14. Gregory D (1994) Geographical Imaginations. Oxford, Blackwell, USA.

15. Harley JB, Woodward D (1987) The History of Cartography. In Cartography in Prehistoric, Ancient and Medieval Europe and the Mediterranean. Chicago, IL: University of Chicago Press, USA.

16. Harley JB, Woodward D (1992) The History of Cartography. In Cartography in the Traditional Islamic and South Asian Societies, Chicago, IL: University of Chicago Press, USA, 2: Book 1.

17. Harley JB, Woodward D (2007) History of Cartography Cartography in the European Renaissance, Chicago, IL: University of Chicago Press, USA, p. 3.

18. Werlen B (1993) Society, action and space: An alternative human geography, Routledge.

19. Said E (1978) Orientalism. New York, Vintage, USA.

20. Crang M (2011) Time In The Sage handbook of geographical knowledge. J Agnew, D Livingstone pp. 331-343.

21. Golledge RG (2002) The Nature of Geographic Knowledge. Annals of the Association of American Geographers 92(1): 1-14.

22. Schaefer FK (1953) Exceptionalism in Geography: A methodological examination. Annals Association of American Geographers 43(3): 226-249.

23. Haggett P (1965) Locational Analysis in Human Geography. London, Arnold.

24. Chorley R, Haggett P (1967) Models in Geography. Methuen, London.

25. Morril R (1970) The Spatial Organization of Society (2 $\left.2^{\text {nd }} E d n.\right)$; Belmont, Wadsworth, CA, USA.

26. Abler R, Adams J, Gould P (1971) Spatial Organisation: The Geographer's View of the World. Prentice Hall, New Jersey, USA.

27. Agnew J, Livingstone D (2011) The Sage handbook of geographical knowledge. Sage, London,UK.

28. Curry MR (1991) Postmodernism, language and the strains of modernism. Annals Association of American Geographers 81(2): 210-228.

29. Massey D (1984) Spatial Divisions of Labour: Social Structures and the Geography of Production, ( $2^{\text {th }}$ edn.); Basingstoke: Macmillan.

30. Massey D (1994) Space, Place and Gender. Minneapolis: University of Minnesota Press, US.

31. Soja EW (1980) The socio-spatial dialectic. Annals of the Association of American Geographers 70(2): 207-225.

32. Pred A (1984) Place as historically contingent process: structuration and the time geography of becoming places. Annals, Association of American Geographers 74(2): 279-297.

33. Pacione M (1990) Conceptual Issues in Applied Urban Geography, Tijdschriftvoor Econ En Soc Geografie 81(1): 3-13. 
34. Harvey D (2006) Space as a key word: N Castree, D Gregory (Eds.); David Harvey A Critical Reader. pp. 270-293.

35. Gulson KN, Symes C (2007) Spatial theories of education: Policy, geography and theory, London and New York, USA.

36. Soja EW (1989) Postmodern Geographies: The Reassertion of Space in Critical Social Theory, London, Verso.

37. Massey D (2005) For Space. Sage, London, UK.

38. Finnegan DA (2008) The Spatial Turn: Geographical Approaches in the History of Science. Journal of the History of Biology 41(2): 369388.

39. Wood D (1992) Guilford, The power of maps 1(4): 399-401.

40. Pickles, J (2004) A History of Spaces: Cartographic Reason, Mapping, and the Geo Coded World. London: Routledge.

41. Johnston RJ, Sidaway JD (2016) Geography and Geographers: AngloAmerican Human Geography since 1945. ( $7^{\text {th }}$ edn.); Routledge, London, UK

42. Couper P (2015) AStudent's Introduction to Geographical Thought: Theories, philosophies, methodologies. Sage, London, UK.

43. Cox K (2014) Making Human Geography. London and New York, USA

44. Nayak A, Jeffrey A (2011) Geographical Thought: An introduction to ideas in human geography. London: Pearson pp. 1-337.

45. Holt Jensen A (2009) Geography: History \& Concepts: A Student's Guide, ( $4^{\text {th }}$ edn.); Sage, London, UK.

46. Martin GJ (2005) All Possible Worlds: A history of geographical ideas $4^{\text {th }}$ (edn.), Oxford University Press, New York, USA

47. Peet R (1998) Modern Geographic Thought. Oxford, Blackwell pp. 1-356.

48. Unwin T (1992) The Place of Geography. Harlow, Longman.

49. Stoddart D (1986) On Geography and its History. Blackwell.

50. Claval P (2015) Spatial Thinking in the Social Sciences: In International Cyclopedia of the Social and Behavioral Sciences, James D. Wright, (2 $\left.{ }^{\text {nd }} e d n.\right) ; 23: 198-201$.

51. Burton I (1963) The quantitative revolution and theoretical geography. Canadian Geographer 7(4): 151-162.

52. Bunge W (1966) Theoretical Geography $\left(2^{\text {nd }} e d n\right)$. Lund Studies in Geography Series C: General and Mathematical Geography (1) Lund: Gleer up, Sweden.

53. Watson JW (1955) Geography: a discipline in distance, Scottish Geographical Magazine 71(1): 1-13.

54. Amedeo D, Golledge RG (1975) An Introduction to Scientific Reasoning in Geography. New York, USA, pp. 431.

55. Haggett P, Clifee AD, Frey AE (1977) Locational Analysis in Human Geography, $2^{\text {nd }}($ edn. $)$; London: Edward Arnold.

56. Harvey D (2005) Space time and the World. In: The people, place, and space reader. Jen Jack Gieseking, et al., (Eds.); (2014) p. 12-16.

57. Thrift N (2006) Space, Theory, Culture and Society 23(2-3): 139-155.

58. Cox K, Golledge RG (1981) Behavioural Problems in Geography Revisited. Methuen, London.

59. Golledge RG, Stimson RJ (1997) Spatial Behavior: A Geographic Perspective. Guilford Press, New York, USA.

60. Tuan YF (1974) Topophilia: A Study of Environmental Perception, Attitudes, and Values. Englewood Cliffs, NJ: Prentice Hall.

61. Tuan YF (1977) Space and Place: The Perspective of Experience. Minneapolis, MN: University of Minnesota Press.
62. Relph E (1976) Place and Placelessness. London, Pion.

63. Buttimer A (1976) Grasping the dynamism of the life world. Annals of the Association of American Geographers 66(2): 277-292.

64. Ley D, Samuels M (1978) Humanistic Geography: Prospects and Problems. Chicago, IL: Maaroufa Press, USA.

65. Hagerstrand T (1985) Time geography: Focus on the corporeality of man, society and environment: In: The Science and Praxis of man society and environment. Aida S pp.193-216.

66. Harvey D (1973) Social Justice and the City. London: Edward Arnold UK.

67. Harvey D (1982) The Limits to Capital, London, Verso, UK.

68. Smith N (1984) 2008 Uneven Development: Nature, Capital and the Production of Space. Oxford, Blackwell.

69. Monk J, Hanson S (1982) On not excluding half of the human in human geography. The Professional Geographer 34(1): 11-23.

70. Women and Geography Study Group (1997) Feminist Geographies: Explorations in Diversity and Difference. Harlow: Addison, Wesley Longman.

71. Corbridge S (1986) Capitalist World Development: A Critique of Radical Development Geography. Macmillan, London.

72. Domosh M (1991) Toward a feminist historiography of geography Transactions of the Institute of British Geographers 16(1): 95-104.

73. Storper M (1997) The Regional World: Territorial Development in a Global Economy. The Guilford Presspp. 1-338.

74. Soja EW (1996) Thirdspace: Journeys to Los Angeles and Other Realand-Imagined Places. Oxford: Blackwell pp.1-348.

75. Jacobs JM (1996) Edge of empire: Post colonialism and the city. Routledge, London, UK.

76. Cresswell T (1996) In Place/Out of Place: Geography, Ideology, and Transgression. University of Minnesota Press, Minneapolis.

77. Doel M (1999) Post-structuralist Geographies: The Diabolical Art of Spatial Science. Edinburgh University Press, Edinburgh.

78. Dear MJ (2000) The Postmodern Urban Condition. Oxford, Blackwell

79. Blunt A, Mc Ewan C (2002) Postcolonial geographies. London, Continuum.

80. Murdoch J (2006) Post-structuralist geography: a guide to relational space. Sage, London,UK.

81. Murdoch J (1997) Inhuman/nonhuman/human: Actor network theory and the prospects for a non-dualistic and symmetrical perspective on nature and society. Environment and Planning D: Society and Space 15(6): 731-756.

82. Law J, Hassard J (1999) Actor-Network Theory and After. Oxford: Blackwell.

83. Gregson N (2000) Taking butler elsewhere: Performativities, spatialities and subjectivities. Environment and Planning D: Society and Space 18(4): 433-452.

84. Whatmore S (2002) Hybrid geographies: Natures, cultures, spaces. Sage.

85. Thrift N (2008) Non-Representational Theory: Space, Politics, Affect, London, Routledge.

86. Anderson B, Harrison P (2010) Taking-Place: Non-Representational Theories and Geography. UK, Ashgate.

87. Greenhough B (2014) More-than-human Geographies: In: The Sage Handbook of Human Geography. Lee R, N Castree, R Kitchin, V Lawson, A Paasi, et al. Sage, London, UK 1: 94-119. 
88. Vannini P (2015) Non-representational methodologies: reenvisioning research. Routledge pp. 1-194.

89. Boyd CP (2017) Non-Representational Geographies of Therapeutic Art Making: Thinking Through Practice. Switzerland.

90. Leitner H, Sheppard E (2013) Un bounding Critical Geographic Research on Cities: The 1990S and beyond. Urban Geography 24(6): 510-528.

91. Simonsen K (1996) What kind of space in what kind of social theory? Progress in Human Geography 20(4): 494-512.

92. Warf B (2015) Space and Social Theory in Geography: In International Cyclopedia of the Social and Behavioral Sciences, James D. Wright, $2^{\text {th }}$ (edn.); Elsevier 23: 82-88.

93. Haines Young RH, Petch JR (1986) Physical Geography: Its Nature and Methods. London: Harper and Row, UK.

94. Rhoads BL, Thorn CE (1996) The Scientific Nature of Geomorphology. Chichester UK, Wiley.

95. Rhoads BL (1999) Beyond Pragmatism: The Value of Philosophical Discourse for Physical Geography. Annals of the Association of American Geographers 89(4): 760-771.

96. Slaymaker O (2009) The Future of Geomorphology, Geography Compass 3(1): 329-349.

97. Inkpen R, Wilson G (2013) Science, Philosophy and Physical Geography. Routledge, London, UK.

98. Hartshorne R (1958a) Perspective on the Nature of Geography Chicago R, McNally, USA.

99. Hartshorne R (1958b) The concept of geography as a science of space, from Kant and Humboldt to Hettner. Annals of the Association of American Geographers 48(2): 97-108.

100. Benko G, Strohmayer U (2004) Human Geography: A History for the $21^{\text {st }}$ Century, London, UK.

101. Blake E (2004) Space, Spatiality, and Archaeology. In: A Companion to Social Archaeology, Lynn Meskell and Robert W Preucel, Malden MA (Eds.); pp. 230-254.

102. Brunet R (2011) Sustainable geography. John Wiley \& Sons, London, UK.

103. Cox K (1976) American geography: social science emergent', Social Science Quarterly 57(1): 182-207.

104. De Certeau M (1984) The Practice of Everyday Life. University of California Press, USA.

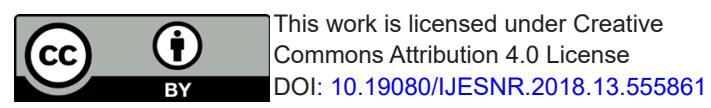

105. Freundschuh S, Egenhofer MJ (1997) Human conceptions of spaces: Implications for geographic information systems. Transactions in GIS 2(4): 361-375.

106. Harley JB, Woodward D (1994) The History of Cartography. In: Cartography in the Traditional East and Southeast Asian Societies, Chicago, IL: University of Chicago Press, USA, 2: Book 2.

107. Harvey D (1984) On the history and present condition of geography: an historical material manifesto. Professional Geographer 36(1): $1-11$.

108. Heidegger M (1978) Being and Time, trans. john Macquarrie and Edward Robinson. Oxford: Basil Blackwell, UK.

109. Hubbard P, Kitchin R, Valentine G (2008) Key texts in human geography. Sage, London, UK.

110. Hubbard P, Kitchin R, Bartley B, Fuller D (2002) Thinking geographically: Space, theory, and contemporary human geography. London, UK.

111. Latour B, Hermant H (1998) Paris: ville invisible. Paris, La Decouverte.

112. Levy J (2014) Inhabiting: In The Sage Handbook of Human Geography. Lee R, N Castree, R Kitchin , V Lawson , A Paasi , et al. (Eds.); Sage, London, UK, 1: 45-68.

113. Nonaka I, Nishiguchi T (2001) Knowledge emergence: Social, technical, and evolutionary dimensions of knowledge Creation. Oxford University Press, New York, USA, pp. 1-320.

114. Schatzki, Theodore R (1991) Spatial Ontology and Explanation Annals of the Association of American Geographers 81(4): 650-670.

115. Smith N (2003) American Empire: Roosevelt's Geographer and the Prelude to Globalization. Berkeley, CA: University of California Press, USA.

116. Soja EW (2010) Seeing Nature Spatially: In: Without Nature? A New Condition for Theology. D. Albertson and C. King (Eds.); Fordham University Press, New York, USA, pp. 181-202.

117. Soja EW (1985) The spatiality of social life: towards a transformative re theorization.In D Gregory, J Urry (Eds.);Social Relations and Spatial Structures. Basingstoke, Macmillan.

118. SojaEW (2000)Postmetropolis: Critical Studies of Cities and Regions. Oxford: Blackwell pp. 1-462.

119. Soja EW (2003) Writing the city spatially, City: analysis of urban trends, culture, theory, policy, action 7(3): 269-280.

120. Thrift N (2009) Space: The Fundamental Stuff of Geography. In N Clifford, S Holloway, SP Rice,G Valentine (Eds.); Key Concepts in Geography (2 $\left.{ }^{\text {nd }} E d n\right)$; Sage, London p. 85-96.

\section{Your next submission with Juniper Publishers will reach you the below assets}

- Quality Editorial service

- Swift Peer Review

- Reprints availability

- E-prints Service

- Manuscript Podcast for convenient understanding

- Global attainment for your research

- Manuscript accessibility in different formats

( Pdf, E-pub, Full Text, Audio)

- Unceasing customer service

Track the below URL for one-step submission https://juniperpublishers.com/online-submission.php 